\section{Biocatalytic Formation of C-C Bonds}

enzymes

kinetic resolution

aerobic oxidative C-C coupling

C-H activation<smiles>[R]c1cc2c(c([R])c1[R])[C@@H](Cc1cccc(O)c1)N(C)CC2</smiles>

reticuline derivatives $\mathrm{R}^{1}, \mathrm{R}^{2}, \mathrm{R}^{3}=\mathrm{H}$ or OMe
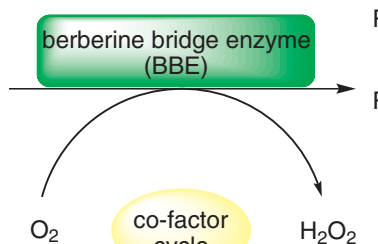

$\mathrm{R}^{2} \mathrm{R}^{3}$<smiles>[CH2+]</smiles>

$\mathrm{R}^{3}$<smiles>Oc1cccc2c1CCCC2</smiles><smiles>[R7]c1cc2c(c([R])c1[R])[C@@H](Cc1cccc(O)c1)N(C)CC2</smiles>

4 examples

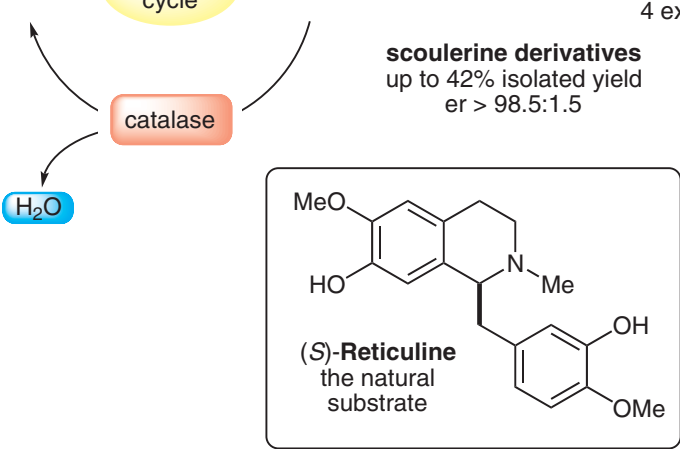

up to $50 \%$ isolated yield er > 98.5:1.5
Significance: The biocatalytic formation of C-C bonds by means of a kinetic resolution of reticuline derivatives is reported. The involved biocataIytic system consists of an aerobic berberine bridge enzyme (BBE) from Eschscholzia californica. Additionally, catalase was incorporated to degrade hydrogen peroxide, which proved to inhibit the enzyme activity at elevated concentrations. The BBE exhibited high tolerance towards virtually any organic solvent and even showed full activity in mixtures of water and toluene. The regioselectivity of the $\mathrm{C}-\mathrm{H}$ activation triggered ring closure represented only a minor problem; the concentrations of the $\mathrm{OH}$ group isomeric scoulerine-type products were below $10 \%$ in all cases.
Comment: Biocatalysis is a growing field in organic synthesis since many chemical transformation can be catalyzed by enzymes. Furthermore, activity and selectivity are often superior to purely chemical methods. In the present report, C-C couplings are catalyzed under entirely environmentally benign conditions. The remarkable fact that the enzyme successfully operates in the presence of high concentrations of organic solvents, shows its high potential for further synthetic applications. However, the bottleneck of the procedure is the high specifity since only few substrates were successfully transformed. A solution to this problem could be provided by directed evolution (see Review below). Further research along these lines involving the powerful class of berberine bridge enzymes (BBE) can be anticipated.

Review: M. T. Reetz Angew. Chem. Int. Ed. 2011, 50, 138-174. 